\title{
INFLUENCE OF METAL IONS ON PELLET MORPHOLOGY AND POLYGALACTURONASE SYNTHESIS BY ASPERGILLUS NIGER 3T5B8
}

\author{
Sônia Couri ${ }^{1 *}$; Gustavo Adolfo Saavedra Pinto ${ }^{2}$; Lilian Ferreira de Senna ${ }^{3}$; Hebe Labarthe Martelli ${ }^{4}$ \\ ${ }^{1}$ Embrapa Agroindústria de Alimentos/CTAA, Engenharia de Alimentos, Rio de Janeiro, RJ, Brasil. ${ }^{2}$ Embrapa Agroindústria \\ Trópical/CNPAT, Fortaleza, Brasil. ${ }^{3}$ Departamento de Química Analítica, Instituto de Química, Universidade do Estado do Rio \\ de Janeiro, Rio de Janeiro, Brasil. ${ }^{4}$ Departamento de Engenharia Bioquímica, Escola de Química, Universidade Federal do Rio de \\ Janeiro, Rio de Janeiro, Brasil.
}

Submitted: January 17, 2002; Returned to authors for corrections: August 19, 2002; Approved: February 04, 2003

\begin{abstract}
The effects of cations addition on pellet morphology and polygalacturonase (PG) synthesis by Aspergillus niger 3T5B8 were studied and compared with a control system. Fe(II), $\mathrm{Cu}(\mathrm{II}), \mathrm{Zn}$ (II) and $\mathrm{Mn}$ (II) were added to the fermentation medium separately, and also as combined groups of cations. The addition of $\mathrm{Fe}^{2+}$ and/or $\mathrm{Zn}^{2+}$ ions was significantly positive to the enzyme production. A positive effect in the biomass content, however, was only obtained when the same metal ions were added separately. On the other hand, $\mathrm{Cu}^{2+}$ and $\mathrm{Mn}^{2+}$ ions had almost no effect on these parameters. The morphology of the pellets was studied by image processing techniques. Small pellets with small cores were usually obtained when $\mathrm{Fe}^{2+}$ and $\mathrm{Zn}^{2+}$ ions were individually or collectively added to the medium. The pellets produced in media containing $\mathrm{Fe}^{2+}$ or $\mathrm{Zn}^{2+}$ ions were compact, while the ones produced in a medium containing both cations were considered diffuse. Autolysis of the core was observed for large control pellets, due to the deficient nutrient transfer to the interior of the pellet. The pellets obtained in a medium containing both $\mathrm{Fe}^{2+}$ and $\mathrm{Zn}^{2+}$ ions were high enzyme producers, probably due to a loose morphology, induced by the presence of combined groups of metal ions in the medium, favoring the nutrient transfer.
\end{abstract}

Key words: metal ions, polygalacturonase, pellet morphology

\section{INTRODUCTION}

In submerged fermentation, the filamentous fungi can be found in several different morphologies, such as dispersed and/or free filaments, swollen cells, pellets, etc. Morphological differentiation may have a significant influence on the formation of metabolic products. Insufficiency of cofactors and oligoelements in fermentation media may decrease the productivity and cause lower yields. It is also known that medium composition may affect fungi morphology in submerged fermentation, and that mycelium morphology can play a role on the yield of citric acid and pectinolytic enzymes $(1,2,3)$. For example, the presence of $\mathrm{Mn}^{2+}$ directly influences the morphology and cell walls composition of A. niger $(3,4)$, as well as the uptake and export of citric acid by this microorganism (5). Clark (6) detected some differences in the internal structure of $A$. niger pellet, when the beet molasses medium was first treated with potassium ferrocyanide. Since trace metals affect the pellet morphology during citric acid production $(3,7)$, it is easy to understand the sequestering action and the morphological influence of chelating agents, such as potassium ferrocyanide and EDTA in fungi fermentations (8).

There are few studies concerning the influence of metal traces on both the morphology of the microorganism and the production of enzymes. Some of them presented evidences that were not well explained. Friedrich et al. (1990) (1) showed that either the presence of $\mathrm{Fe}^{2+}$ or the absence of this cation from the medium (by using potassium ferrocyanide) modified the pellet morphology and the enzyme activity. Unfortunately, the

\footnotetext{
* Corresponding author. Mailing address: Embrapa Agroindústria de Alimentos / Laboratório de Processos Fermentativos. Av. das Américas, 29501. Guaratiba, Rio de Janeiro, RJ, Brasil. 23020-470. Fax: (+5521) 2410-1090. E-mail: scoury@ctaa.embrapa.br
} 
use of metal reactors also affected the fungi growth and the results found in these experiments. The great majority of the works, however, was concerned with the physiological effects of the addition of the metals to the medium. Wang and Rakshit (9) showed that the additions of $\mathrm{Fe}^{2+}, \mathrm{Cu}^{2+}$ and $\mathrm{Zn}^{2+}$ presented no obvious effect on the extracellular transferase synthesis by Aspergillus foetidus NRRL337, in the ranges tested. Ghosh et al. (10) observed that the individual addition of $10 \mathrm{mM}$ of $\mathrm{Fe}^{2+}$, $\mathrm{Cu}^{2+}, \mathrm{Zn}^{2+}$ and $\mathrm{Mn}^{2+}$ promoted an increase in the thermostable xylanase production by Aspergillus sydowii MG49, although $\beta$-xylosidase synthesis decreased more than $50 \%$. For the production of glucose oxidase by $A$. niger ZBY7, the addition of low concentrations of $\mathrm{Mn}^{2+}$ increased the enzyme synthesis, while high concentrations showed an inhibitory effect. The addition of $\mathrm{Zn}^{2+}$ was harmful, even at low concentrations (11).

The relationship between the fungi morphology and the enzyme production in submerged fermentation has also not been widely reported. In shake flask fermentation, the growth of diffuse and compact mycelia by A. niger strains for polygalacturonase synthesis was studied by Hermersdörfer $e t$ al. (12). They found a direct correlation between the compactness of the pellet and the polygalacturonase synthesis, but despite having used trace metals as micronutrients, the authors excluded reference to them in their final conclusions. Carlsen et al. (13) showed that the specific production of $\alpha$ amylase was significantly higher for filamentous growth than for pellets of Aspergillus oryzae. More recently, Schürgerl et al. (14) reported on a very extensive study concerning the influence of the process parameters on the morphology, and the xylanase production by Aspergillus awamori.

In this work, the effects of the addition of different concentrations and combinations of cations to a defined medium, on the morphology of the A. niger pellets and polygalacturonase $(\mathrm{PG})$ synthesis were studied. The goals were the improvement of enzyme synthesis, and the assessment of its relationship to pellet morphology.

\section{MATERIALS AND METHODS}

\section{Microorganism, maintenance and propagation}

A. niger 3T5B8, a double mutant from the Embrapa Food Technology collection (15), was maintained on dry sand at $18^{\circ} \mathrm{C}$ and activated in basic agar slant (16).

\section{Fermentation}

The experiments were carried out in $500 \mathrm{~mL}$ shake flasks containing $100 \mathrm{~mL}$ of medium, inoculated with $10^{5}$ conidia per $\mathrm{mL}$ of medium and incubated at $32^{\circ} \mathrm{C}$ and $245 \mathrm{rpm}$ for 40 hours.

\section{Basal medium composition $(\mathrm{g} / \mathrm{L})$ \\ Sucrose 24.0, (NH4)2SO4 5.0, MgSO4.7H2O 0.5, KH2PO4 $1.0, \mathrm{KCl} 0.1$; initial $\mathrm{pH} 4.5$. High grade reagents were used.}

\section{Addition of cations to the fermentation medium}

Sulfate salts of $\mathrm{Fe}^{++}, \mathrm{Cu}^{++}, \mathrm{Zn}^{++}$and $\mathrm{Mn}^{++}$were added to the fermentation medium, based on the values proposed in the literature for citric acid or pectinolytic enzymes production $(1,12,17)$. Table 1 shows the levels adopted for this study. A two level factorial design was utilized for the experimental procedure.

\section{Analytical methods}

The biomass concentration was determined by filtering the culture, using a pre-dried and pre-weighted paper (Whatman no.1). The collected mycelia were dried at $90^{\circ} \mathrm{C}$ to constant weight. The supernatants were used for enzyme assays. To analyze the polygalacturonase (PG) activity (EC 3.2.1.15), 0.1 $\mathrm{mL}$ of the enzymatic solution $4.0 \mathrm{~mL}$ citrate buffer, containing $0.25 \%$ polygalacturonic acid solution $(0.1 \mathrm{M} ; \mathrm{pH} 4.2)$ was incubated for 30 minutes at $35^{\circ} \mathrm{C}$, and the release of sugars was measured. One unit of enzyme activity was defined as the amount of enzyme that produced one $\mu \mathrm{mol}$ of galacturonic acid/ min, under the assay conditions (17). The Somogyi method (18) was used in the quantification of reducing groups.

\section{Fungi morphology}

Samples of the pellets were collected during fermentation, and observed under a light microscope. The morphology of digitized images was evaluated by using an image processing software (Image Tool for Windows, 2.0). A series of mathematical operations were used to process the digital images and to obtain the morphological parameters $(19,20,21,22)$. As an example, the image processing of a pellet produced in the control medium is shown in Fig. 1. The morphological parameters were measured after processing (21). The diameter (D), the perimeter (P), and the diameter of the core (d), of the pellets were the morphological parameters measured, and their mean values were estimated. Approximately 20 samples were evaluated for each condition studied. The pellet and core areas ( $A_{p}$ and $A_{c}$, respectively), the pellet volume $\left(V_{p}\right)$, the $A_{c} / A_{p}$ percent ratio, the annular area $\left(A_{a}\right)$, and the $D / d$ ratio, were calculated based on the above mentioned measurements. The pellet diameter (D) was measured by joining two extreme filament tips. The core diameter (d) was obtained in a similar way, considering the non-filamentous region of the pellet. The perimeter of the pellet $(\mathrm{P})$ was measured by joining the tips of the filaments that originate in the core of the pellet. The fungi morphology was then related to the polygalacturonase activity and the biomass production.

Table 1. Cations added to the basal media.

\begin{tabular}{ccccc}
\hline LEVEL & \multicolumn{4}{c}{ METAL ION $(\mathrm{mg} / \mathrm{L})$} \\
\hline & $\mathrm{Fe}^{++}$ & $\mathrm{Cu}^{++}$ & $\mathrm{Zn}^{++}$ & $\mathrm{Mn}^{++}$ \\
\cline { 2 - 5 } $\mathbf{- 1}$ & 0 & 0 & 0 & 0 \\
$+\mathbf{1}$ & 4.60 & 1.50 & 1.10 & $6.5 \times 10^{-2}$ \\
\hline
\end{tabular}




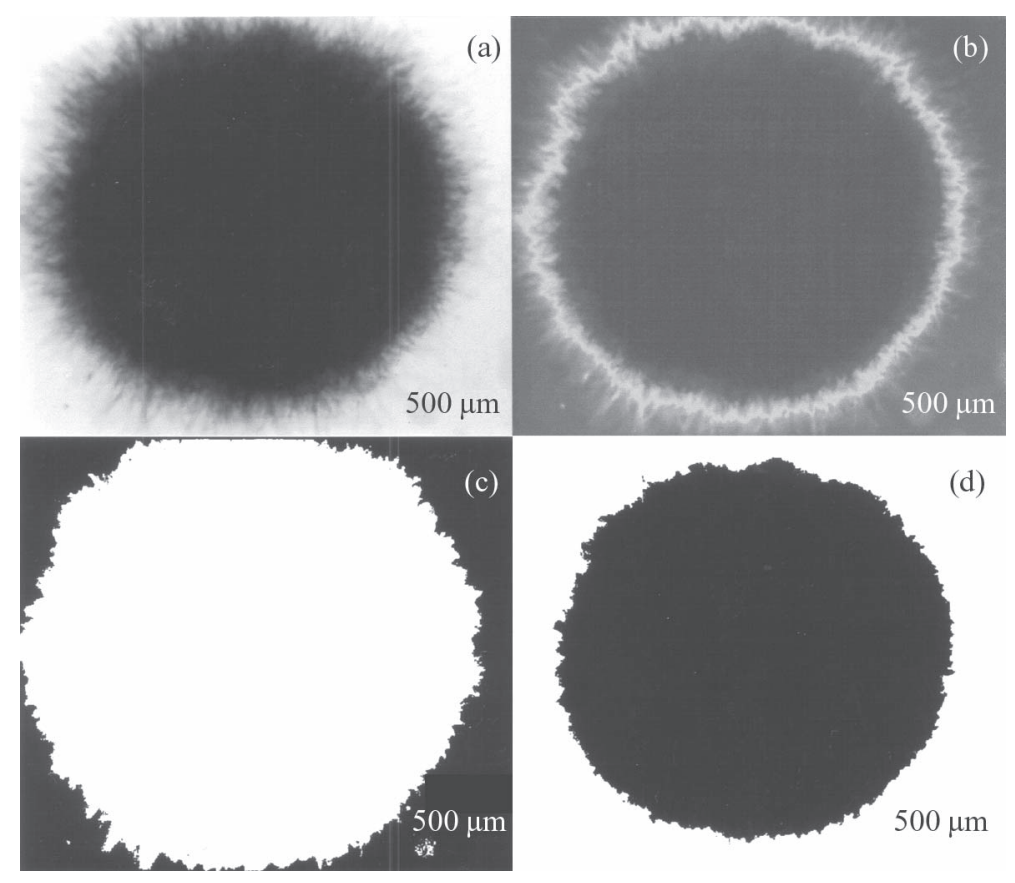

Figure 1. Main image process operations used to analyze the pellets (control pellets) (21): (a) digitized gray scale image; (b) pseudo-colors were applied to the image to show the differences between the core and the whole pellet; (c) use of a threshold and open operations to produce a binary inverse image of the whole pellet; (d) use of a threshold and open operations to produce a binary image of the core of the pellet. that $\mathrm{Fe}^{2+}$ and $\mathrm{Zn}^{2+}$ ions had a significant effect on the PG activity. The addition of these ions caused an increase in the amount of PG synthesized. The joint addition of both ions, also showed a positive influence on PG activity, and high amounts of enzyme can be expected under this condition. Similar results are obtained when $\mathrm{Fe}^{2+}$ and $\mathrm{Cu}^{2+}$ ions are added together, although the sole addition of $\mathrm{Cu}^{2+}$ ions does not affect either the PG activity or the biomass amount. The addition of $\mathrm{Zn}^{2+}$ or $\mathrm{Fe}^{2+}$ ions also had a significant effect on biomass production. However, the same effect was not observed for the joint addition of $\mathrm{Fe}^{2+}$ and $\mathrm{Zn}^{2+}$ or $\mathrm{Fe}^{2+}$ and $\mathrm{Cu}^{2+}$ ions.

It is known that zinc deficiency in fungi growth causes a decrease in the activity of several enzymes of the fungi metabolism (23). Conversely, if this metal is present, the opposite result could be expected. A positive effect on PG activity can be seen in Fig 2.a. Roukas and Kolzeikidou (24) observed an increase in citric acid production by the addition of $\mathrm{Fe}^{2+}$ and $\mathrm{Zn}^{2+}$ ions to the fermentation medium. Analogous results had been reported earlier by Snell and Schweiger (25), showing that under this condition, a synergetic effect was probably influencing the metabolic productions by Aspergillus niger. Friedrich et al. (1) observed an increase in biomass concentration in the presence of a high amount of $\mathrm{Fe}^{2+}$ ions in the fermentation medium. On the other hand, the addition of $\mathrm{Cu}^{2+}$ ions usually has an inhibitory influence on the fungi growth and

\section{Pellet density}

20 pellets of the control, and 20 other developed under the best production conditions were collected in a filter paper, and dried at $90^{\circ} \mathrm{C}$ until constant weight was obtained. The calculated mass for one pellet was divided by the mean volume, estimated by image analysis.

\section{RESULTS AND DISCUSSION}

Although high-grade reagents had been used, the amount of micronutrients (Fe, $\mathrm{Cu}, \mathrm{Mn}$ and $\mathrm{Zn}$ ) in the basal medium was analyzed by atomic absorption spectrometry. The micronutrients content was not significant (17) and the basal medium was considered to be free of them.

\section{Effect of cation addition on polygalacturonase production}

The effect of cation addition to the fermentation medium was tested in a series of experiments. Previous experiments (17) have shown that the samples obtained after $40 \mathrm{~h}$ of fermentation were the most representative in morphology and PG activity. Table 2 shows the results for the experimental design proposed.

Fig. 2 shows the Pareto analysis for PG synthesis and biomass production $(\mathrm{p}<0.1)$. The statistical analysis reveals the citrate transport in citric acid production $(3,5,17)$. Comparable results were observed here for PG synthesis and biomass production (Fig. 2). Roukas and Kolzeikidou (24) also observed

Table 2. PG activity, biomass concentration in 40 hours of fermentation.

\begin{tabular}{rrrrcc}
\hline $\mathrm{Fe}^{++}$ & $\mathrm{Cu}^{++}$ & $\mathrm{Zn}^{++}$ & $\mathrm{Mn}^{++}$ & PG activity $(\mathrm{U} / \mathrm{mL})$ & Biomass $(\mathrm{g} / \mathrm{L})$ \\
\hline-1 & -1 & -1 & -1 & 2.8 & 2.3 \\
1 & -1 & -1 & -1 & 2.7 & 3.6 \\
-1 & 1 & -1 & -1 & 2.9 & 3.1 \\
1 & 1 & -1 & -1 & 2.5 & 2.0 \\
-1 & -1 & 1 & -1 & 3.3 & 4.1 \\
1 & -1 & 1 & -1 & 5.0 & 5.5 \\
-1 & 1 & 1 & -1 & 2.8 & 4.8 \\
1 & 1 & 1 & -1 & 6.0 & 5.8 \\
-1 & -1 & -1 & 1 & 3.2 & 2.9 \\
1 & -1 & -1 & 1 & 2.8 & 1.8 \\
-1 & 1 & -1 & 1 & 1.8 & 1.9 \\
1 & 1 & -1 & 1 & 3.8 & 3.0 \\
-1 & -1 & 1 & 1 & 2.8 & 2.5 \\
1 & -1 & 1 & 1 & 5.2 & 6.0 \\
-1 & 1 & 1 & 1 & 3.0 & 5.3 \\
1 & 1 & 1 & 1 & 6.3 & 6.4 \\
\hline
\end{tabular}



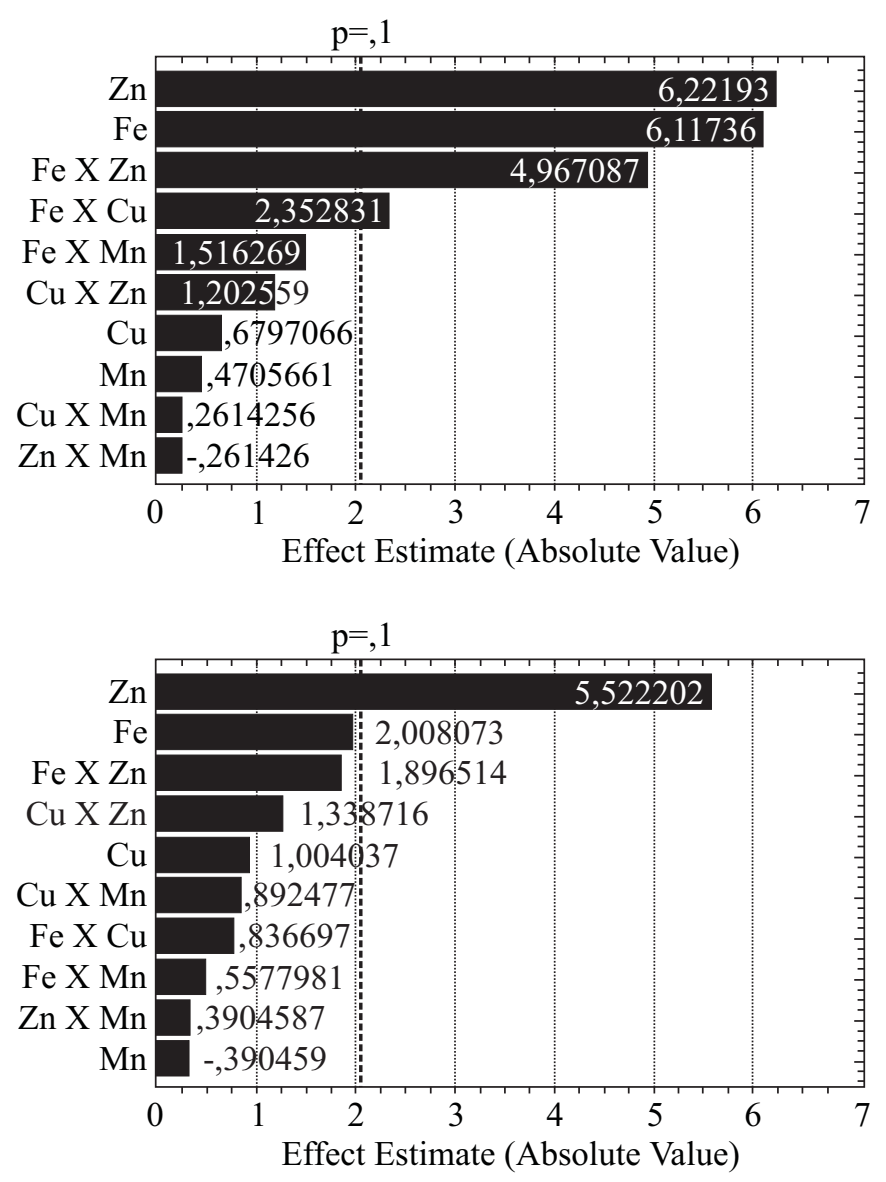

Figure 2. Pareto chart of standardized effects for PG activity (a) and biomass (b), in 40 hours of fermentation.

that the addition of $\mathrm{Cu}^{2+}$ ions to a medium containing $\mathrm{Fe}^{2+}$ ions decreased the citric acid production by $10 \%$. Schweiger ( 7 ) also verified this antagonistic effect between $\mathrm{Cu}^{2+}$ and $\mathrm{Fe}^{2+}$. However, when $\mathrm{Cu}^{2+}$ and $\mathrm{Fe}^{2+}$ ions were added together to the fermentation medium described in this work, this adverse effect could only be verified on the biomass production, although it was not significant.

On the other hand, it is interesting to note that the addition of $\mathrm{Mn}^{2+}$ ions has no significant effect either on the PG synthesis or the biomass production, even when combined with any of the cations studied here. Since this cation plays an important role in the production of citric acid by Aspergillus niger, one would expect an opposite behavior. Manganese deficiency has been shown to result in a decrease in the concentration of several enzymes connected with anabolism, and with the termination of the growth phase (26). Ma et al. (27) demonstrated that protein synthesis and RNA were not influenced by the presence of $\mathrm{Mn}^{2+}$ ions. On the other hand, manganese deficiency caused an increase of protein degradation and a malfunction of ribosomal activity. In this way, an increase in the PG activity could be observed in media containing $\mathrm{Mn}^{2+}$ ions. However, under the conditions used in this work, this effect was not significant (Fig. 2).

\section{Effect of cation addition on pellet morphology}

Since the addition of isolated $\mathrm{Cu}^{2+}$ and $\mathrm{Mn}^{2+}$ ions was not significant for either PG synthesis or biomass production, the effect of these ions on the pellet morphology was not evaluated. Thus, based on the results of Pareto analysis (Fig. 2), only the effect of the addition of $\mathrm{Zn}^{2+}$ and/or $\mathrm{Fe}^{2+}$ ions on the pellet morphology was estimated. Table 3 shows the statistical analysis of the main parameters obtained by image processing technique $(\mathrm{p}<0.1)$.

The presence of $\mathrm{Fe}^{2+}$ and/or $\mathrm{Zn}^{2+}$ ions affected significantly the diameter of the pellet, the diameter of the core (the internal region with high degree of entanglement) and the perimeter of the pellet. Table 3 shows that the addition of only one of the ions caused a negative effect on both the pellet and the core diameters, as well as on the perimeter of the pellet. Conversely, the joint addition of the ions provoked a positive effect on all of the above mentioned parameters.

Table 4 shows the average values of these results, as well as other calculated parameters used to describe the morphology of the pellets. When compared with the basal medium (control), there is a decrease in the average values of the pellet diameter and perimeter for $\mathrm{Zn}^{2+}$ and/or $\mathrm{Fe}^{2+}$ ions addition. The results calculated from these parameters (pellet area and volume) show the same behavior. Other interesting points to observe in Table 4 are the similar average values measured for the core diameters of the pellets produced in media containing $\mathrm{Fe}^{2+}$ and/or $\mathrm{Zn}^{2+}$ ions. Thus, smaller pellets, with smaller cores, tend to be produced no matter if $\mathrm{Zn}^{2+}, \mathrm{Fe}^{2+}$ or both ions are added to the fermentation medium.

Table 3. Effect of addition of $\mathrm{Fe}$ and $\mathrm{Zn}$ ions on some morphologic parameters.

\begin{tabular}{|c|c|c|c|c|}
\hline Parameter & Effect & Value & Stand. Err. & $\mathrm{p}$ \\
\hline \multirow[t]{3}{*}{ Pellet Diameter } & $\mathrm{Fe}$ & -0.5325 & 0.1573 & 0.0276 \\
\hline & $\mathrm{Zn}$ & -0.3775 & & 0.0743 \\
\hline & $\mathrm{Fe} \mathrm{X} \mathrm{Zn}$ & 1.0725 & & 0.0024 \\
\hline \multirow[t]{3}{*}{ Core Diameter } & $\mathrm{Fe}$ & -0.3350 & 0.1222 & 0.0518 \\
\hline & $\mathrm{Zn}$ & -0.3050 & & 0.0670 \\
\hline & $\mathrm{Fe} X \mathrm{Zn}$ & 0.4100 & & 0.0284 \\
\hline \multirow[t]{3}{*}{$\begin{array}{l}\text { Core Diam. / } \\
\text { Pellet Diam. }\end{array}$} & $\mathrm{Fe}$ & 0.0115 & 0.0277 & 0.6987 \\
\hline & $\mathrm{Zn}$ & -0.0102 & & 0.7307 \\
\hline & $\mathrm{Fe} X \mathrm{Zn}$ & -0.0799 & & 0.0448 \\
\hline \multirow[t]{3}{*}{ Pellet Perimeter } & $\mathrm{Fe}$ & -1.9738 & 0.7087 & 0.0164 \\
\hline & $\begin{aligned} Z n \\
X\end{aligned}$ & $\begin{array}{r}-1.5488 \\
3.0263\end{array}$ & & 0.0494 \\
\hline & & & & \\
\hline
\end{tabular}


Table 4. Main parameters measured and calculated by image processing.

\begin{tabular}{lrrrr}
\hline \multicolumn{1}{c}{ Parameters } & \multicolumn{1}{c}{ Control } & \multicolumn{1}{c}{$\mathrm{Fe}^{++}$} & \multicolumn{1}{c}{$\mathrm{Zn}^{++}+\mathrm{Fe}^{++}$} \\
\hline Pellet Diameter $(\mathrm{mm})$ & $6.36 \pm 0.21$ & $4.66 \pm 0.35$ & $4.61 \pm 0.38$ & $5.24 \pm 0.56$ \\
Pellet Area $\left(\mathrm{A}_{\mathrm{p}}\right)\left(\mathrm{mm}^{2}\right)$ & $31.77 \pm 5.72$ & $17.12 \pm 2.54$ & $16.76 \pm 2.82$ & $21.86 \pm 3.63$ \\
Pellet Volume $\left(\mathrm{mm}^{3}\right)$ & $134.70 \pm 37.82$ & $53.70 \pm 11.89$ & $52.16 \pm 13.30$ & $75.33 \pm 14.16$ \\
Perimeter $(\mathrm{mm})$ & $21.18 \pm 0.10$ & $14.78 \pm 0.66$ & $14.48 \pm 1.06$ & $16.66 \pm 0.12$ \\
Core Diameter $\left(\mathrm{mm}^{2}\right)$ & $4.47 \pm 0.19$ & $3.72 \pm 0.12$ & $3.52 \pm 0.11$ & $3.62 \pm 0.26$ \\
Core Area $\left(\mathrm{A}_{\mathrm{c}}\right)\left(\mathrm{mm}^{2}\right)$ & $15.69 \pm 0.85$ & $10.84 \pm 0.70$ & $9.74 \pm 0.62$ & $10.29 \pm 1.85$ \\
Annular area $\left(\mathrm{mm}^{2}\right)$ & $16.08 \pm 5.78$ & $6.28 \pm 2.83$ & $7.02 \pm 2.82$ & $11.57 \pm 4.07$ \\
$\mathrm{~A}_{\mathrm{c}} / \mathrm{A}_{\mathrm{p}}$ X 100\% & $49 \%$ & $63 \%$ & $58 \%$ & $47 \%$ \\
Diameter Ratio & 1.42 & 1.25 & & 1.31 \\
\hline
\end{tabular}

However, by observing the diameter ratio $(\mathrm{D} / \mathrm{d})$, it can be noted that the average value obtained for the pellets produced in a medium where both $\mathrm{Fe}^{2+}$ and $\mathrm{Zn}^{2+}$ ions have been added is higher than the values obtained with the media containing the individual ions, being similar to that accomplished with the control medium. This agrees with the results shown in Table 3. The $A_{c} / A_{p}$ percent ratio shows the percent amount of pellet entangled in the core. The average value of this parameter as obtained in a medium containing $\mathrm{Zn}^{2+}$ and $\mathrm{Fe}^{2+}$ ions is lower than the ones obtained in an $\mathrm{Fe}^{2+}$ or $\mathrm{Zn}^{2+}$ medium, and is comparable to the control medium value. Moreover, it follows that less than $50 \%$ of the pellet is entangled in the core. Therefore, pellets smaller than the ones produced in the control medium, showing similar values of diameter ratio and $A_{c} / A_{p}$ percent ratio, are obtained in a $\mathrm{Zn}^{2+}$ and $\mathrm{Fe}^{2+}$ added medium. All these observations support the hypothesis that diffuse pellets are formed in the control and in $\mathrm{Zn}^{2+}$ and $\mathrm{Fe}^{2+}$ ions containing media. On the other hand, compact pellets can be observed in media containing only one of the cations. These results corroborated light microscope observations.

\section{Relationship between pellet morphology and PG activity}

Hermersdörfer et al. (12) showed that PG activity increased with the degree of compactness of mycelium. In this work where A. niger 3T5B8 was used, it was observed that PG activity increased in the $\mathrm{Fe}^{2+}$ and $\mathrm{Zn}^{2+}$ medium, when slightly diffused pellets were formed. The diffuse structure of pellets favors nutrient flux, facilitating cell metabolism, i.e., cell growth and enzyme biosynthesis. The combination of the cations $\mathrm{Fe}^{2+}$ and $\mathrm{Zn}^{2+}$ ions influenced the cellular structure of the pellet, modifying its morphology and affecting the synthesis of PG. A synergetic effect could probably be affecting the metabolic productions by $A$. niger, as was proposed by Snell and Schweiger (25). The results obtained with the strain 3T5B8 were similar to those observed for citric acid fermentation, in which the controlled addition of cations is always needed to maintain the pellet morphology.

However, although the control pellets were low enzyme and low biomass producers $(2.8 \mathrm{U} / \mathrm{mL}$ and
$2.3 \mathrm{~g} / \mathrm{L}$, respectively) when compared to $\mathrm{Fe}^{2+}$ and $\mathrm{Zn}^{2+}$ medium pellets $(5.0 \mathrm{U} / \mathrm{mL}$ and $5.5 \mathrm{~g} / \mathrm{L}$, respectively), the control pellets were also considered diffuse. Conversely, if the specific yield (enzyme activity/biomass content) is taken into account, the value obtained for control pellets is higher than the $\mathrm{Fe}^{2+}$ and $\mathrm{Zn}^{2+}$ medium ones (1217 and $935 \mathrm{U} / \mathrm{g}$, respectively). It is apparent that the morphological definition of a pellet as being "diffuse" or "compact", doe not in itself explain the above mentioned results. Even though the morphological parameters of the pellets produced in both the control and the $\mathrm{Fe}^{2+}$ and $\mathrm{Zn}^{2+}$ ions containing media are similar, the control pellets were larger, with high average values of core diameters. High diameter pellets tend to suffer autolysis of the cells in their inner part, particularly if their cores are also large, as is the case here. Table 5 presents the average weight and density of the pellets produced in the control medium and in the one where both $\mathrm{Fe}^{2+}$ and $\mathrm{Zn}^{2+}$ ions were added. It can be observed that the average weight as well as the density of the pellets produced in the control medium are lower than the ones obtained in a medium containing the cations. This result indicates that the control pellets are probably suffering autolysis, due to their high core and volume, making it difficult for the nutrients to be transported to the core. Earlier light microscopic observations showed that the control pellets presented autolysed cells (17). Thus, although the ratio values have defined the control pellets as "diffuse", the high hyphae entanglement had probably produced a compact core, where the inner part was lysed due to a deficient nutrient transportation. The high annular area of the pellet could not compensate this effect, and the enzyme activity was low. In addition, the lysed inner cells were probably releasing part of the enzyme that was inside them, which could explain the elevated specific yield value.

Table 5. Average weight and density of the pellets.

\begin{tabular}{lcc}
\hline \multicolumn{1}{c}{ Parameters } & Control & $\mathrm{Zn}^{++}+\mathrm{Fe}^{++}$ \\
\hline Pellet Weight $(\mathrm{g})$ & $1.10 \times 10^{-4} \pm 8.50 \times 10^{-6}$ & $2.70 \times 10^{-4} \pm 3.25 \times 10^{-5}$ \\
Pellet Density $(\mathrm{g} / \mathrm{mL})$ & $8.17 \times 10^{-4} \pm 6.31 \times 10^{-5}$ & $2.64 \times 10^{-3} \pm 3.18 \times 10^{-4}$ \\
\hline
\end{tabular}




\section{ACKNOWLEDGMENTS}

The authors would like to thank FAPERJ (Fundação de Amparo à Pesquisa do Rio de Janeiro) and CNPq (Conselho Nacional de Pesquisa e Desenvolvimento) for financial support.

\section{RESUMO}

\section{Influência dos íons metálicos na morfologia do agregado e na síntese de poligalacturonase por Aspergillus niger 3T5B8}

O efeito da adição de cátions na morfologia do agregado e na síntese de poligalacturonase (PG) por Aspergillus niger 3T5B8 foi estudado e comparado com um sistema controle. $\mathrm{Fe}(\mathrm{II}), \mathrm{Cu}(\mathrm{II}), \mathrm{Zn}$ (II) and $\mathrm{Mn}$ (II) foram adicionados ao meio de fermentação, tanto separadamente, como em grupos de cátions. $\mathrm{A}$ adição dos íons $\mathrm{Fe}^{2+}$ e/ou $\mathrm{Zn}^{2+}$ foi positivamente significante para a produção da enzima. Um efeito similar no teor de biomassa, contudo, só pode ser observado quando os mesmos íons foram adicionados isoladamente. Por outro lado, os íons $\mathrm{Cu}^{2+} \mathrm{e} \mathrm{Mn}^{2+}$ não afetaram significativamente estes parâmetros. Utilizando-se técnicas de processamento de imagens para o estudo da morfologia dos pellets, observou-se que pequenos aglomerados, com pequenos núcleos, foram geralmente obtidos quando os cátions $\mathrm{Fe}^{2+} \mathrm{e} \mathrm{Zn}^{2+}$ foram adicionados ao meio, seja isolada ou simultaneamente. Os aglomerados produzidos em meios contendo íons $\mathrm{Fe}^{2+}$ ou $\mathrm{Zn}^{2+}$ eram compactos, enquanto que aqueles produzidos em meios contendo ambos os cátions foram considerados difusos. A autólise do núcleo foi observada para os grandes agregados produzidos no meio controle, devido ao transporte deficiente de nutrientes para o seu interior. Os agregados produzidos em meio contendo os íons $\mathrm{Fe}^{2+}$ e $\mathrm{Zn}^{2+}$ foram grandes produtores de enzima, provavelmente devido a uma morfologia mais "frouxa", induzida pela presença combinada destes metais no meio, favorecendo o transporte de nutrientes.

Palavras-chave: íons metálicos, poligalacturonase, morfologia do agregado.

\section{REFERENCES}

1. Friedrich, J.; Cimerman, A.; Steiner, W. Production of pectolytic enzymes by Aspergillus niger: effect of inoculum size and potassium hexacyanoferrate 2-trihydrate, App. Microbiol. Biotech., 33: 377$381,1990$.

2. Nielsen, J.; Krabben, P. Hyphal growth and fragmentation of Penicillium chrysogenum in submerged cultures. Biotechnol. Bioeng., 46: 588-598, (1995).

3. Papagianni, M.; Mattey, M.; Kristiansen, B. Morphology and citric acid production of Aspergillus niger PM 1. Biotechnol. Let., 16: (9) 929-934, 1994.
4. Kisser, M.; Kubicek, C.P.; Röhr, M. Influence of manganese on morphology of cell wall composition of Aspergillus niger during citric acid fermentation. Arch. Microbiol., 128: 26-33, 1980.

5. Netik, A.; Torres, N.V.; Riol, J.M.; Kubicek, C.P. Uptake and export of citric acid by $A$. niger is reciprocally regulated by manganese ions. Bioch. Bioph. Acta, 1326: 287-294, 1997.

6. Clark, D.S. Submerged citric acid fermentation of ferrocyanide treated beat molasses: morphology of pellets of Aspergillus niger. Can. J. Microb., 8: 133-136, 1966.

7. Schweiger, L.B. Method for producing citric acid by fermentation US Patent 2.353.771, 1961.

8. Gibbs, P.A.; Sevior, R.J.; Schimid, F. Growth of filamentous fungi in submerged culture: problems and possible solutions. Crit. Rev. Biotechnol., 20 (1): 17-48, 2000.

9. Wang, X.D.; Rakshit, S.K. Improved extracellular transferase enzyme production by Aspergillus foetidus for synthesis of isooligosaccharides. Bioproc. Eng., 20: 429-434. 1999.

10. Ghosh, M.; Das, A.; Mishira, A.K.; Nanda, G. Aspergillus sydowii MG49 is a stronger producer of thermostable xylanolytic enzymes. Enz. Microbial. Technol., 15: 703-709, 1993.

11. Liu, J.Z.; Huang, Y.Y.; Liu, L.; Weng, L.P.; Ji, L.N. Effects of metal ions on simultaneous production of glucose oxidase and catalase by Aspergillus niger. Lett. App. Microbiol., 32: 16-19, 2001.

12. Hermersdörfer, H.; Leuchtenberger, A.; Warsack, C.H.; Ruttloff, H. Influence of culture conditions on mycelial strucuture and polygalacturonase synthesis of Aspergillus niger. J. Basic Microbiol., 27: 309-315, 1987.

13. Carlsen, M.; Spohr, A.B.; Nielsen, J.; Villadsen, J. Morphology and physiology of an a-amylase producing strain of Aspergillus oryzae batch cultivations. Biotechnol. Bioeng., 49: 266-276, 1996.

14. Schürgerl, K.; Gerlach, S.R.; Siedenberg, D. Influence of the process parameters on the morphology and enzyme production of Aspergilli. Adv. Biochem. Eng. Biotechnol., 60: 195-266, 1998.

15. Couri, S.; Farias, A.X. Genetic manipulation of Aspergillus niger for increased synthesis of pectinolytic enzymes. Rev. Microbiol., 26(4): 314-317, 1995.

16. Martin, S.M. Conservation of microorganism. Ann. Rev. Microbiol., 18: 1-16, 1964.

17. Couri, S. Efeito de cátions na morfologia do agregado e na produção de poligalacturonase por A. niger Mutante 3T5B8, D.Sc. Theses, Rio de Janeiro, 1993, 199p. (Escola de Química, Universidade Federal do Rio de Janeiro).

18. Somogyi, M. Notes on sugar determination. J. Biol. Bioch., 195: 1923, 1952.

19. Cox, P.W.; Thomas, C.R. Classification and measurement of fungal pellets by automated image analysis, Biotechnol. Bioeng., 39: 945952, 1992.

20. McIntyre, M.; Berry, D.R.; Eade, J.K.; Cox, P.W.; Thomas, C.R.; McNeil, B. Manual and semi-automated morphological analysis of Penicillium chrysogenum chemostat cultures. Biotechnol. Bioeng, 12(9): 671-675, 1998.

21. Senna, L.F.; Couri, S. Preliminary results on biomass characterization using image analysis, Microscop. Acta, 8(A): 112-113, 1999.

22. Tucker, K.G.; Thomas, C.R. Mycelial morphology: the effect of spore inoculum level Biotechnol. Let., 14(11): 1071-1074, 1992.

23. Hughes, M.N.; Poole, R.K. Metal nutrition: the supply and analysis of metals in microbial cultures. Metals and Microorganisms, New York: Chapman \& Hall, 1989.

24. Roukas, T.; Kolzeikidou, P. Influence of some trace metals and stimulants on citric acid production from brewery wastes by Aspergillus niger. Enz. Microbiol. and Technol., 9: 291-294, 1987.

25. Snell, R.L.; Schweiger, L.B. Production of citric acid by fermentation US Patent 2.492.667, 1949.

26. Kubicek, C.P.; Hampel, W.; Rohr, M. Manganese deficiency leads to elevated amino-acid pools in citric acid accumulation Aspergillus niger. Arch. Microbiol., 123: (1) 73-79, 1979.

27. Ma, H.; Kubicek, C.P.; Rohr, M. Metabolic effects of manganese deficiency in Aspergillus niger - evidence for increased proteindegradation. Arch. Microbiol., 141: (3) 266-268, 1985. 